\title{
Mechanisms of mitogenic and anti-apoptotic signaling by glucose-dependent insulinotropic polypeptide in $\beta($ INS-1)-cells
}

\author{
A Trümper, K Trümper and D Hörsch \\ Department of Internal Medicine, Division of Gastroenterology and Endocrinology, Philipps-University, Baldingerstrasse, D-35033 Marburg, Germany \\ (Requests for offprints should be addressed to D Hörsch; E-mail: hoerschd@post.med.uni-marburg.de)
}

\begin{abstract}
Glucose-dependent insulinotropic polypeptide (GIP) acts as a glucose-dependent growth factor for $\beta$-cells. Here we show that GIP and glucose also act synergistically as anti-apoptotic factors for $\beta$-cells, using the welldifferentiated $\beta$-cell line, INS-1. Mitogenic and anti-apoptotic signaling of GIP were dependent upon pleiotropic activation of protein kinase A (PKA)/cAMP regulatory element binder (CREB), mitogen-activated protein kinase (MAPK) and phosphatidylinositol 3-kinase (PI3-kinase)/PKB signaling modules. The signaling modules activated by GIP were dependent on glucose metabolism and calcium influx and were tightly linked by multiple activating and inhibiting cross-talk. These interactions included: (i) a central role of tyrosine phosphory-
\end{abstract}

lation for stimulation of PKA/CREB, MAPK and PI3kinase/PKB, (ii) inhibition of PKA/CREB by the MAPK pathway at the level of MAPK kinase-1 or downstream, (iii) activation of MAPK signaling by PI3-kinase and PKA at the level of extracellular-signal regulated kinase $1 / 2$ or upstream, and (iv) activation of PKB by MAPK and PKA signaling at the level of PKB or upstream. Furthermore, we demonstrated inhibition of CREB signaling by $\mathrm{Ca}^{2+}$ / calmodulin kinase I/IV. These results indicated that GIP acts as a mitogenic and anti-apoptotic factor for $\beta$-cells by pleiotropic activation of tightly linked signaling pathways in $\beta$-cells.

Journal of Endocrinology (2002) 174, 233-246

\section{Introduction}

The postprandial secretion of insulin is regulated by hormonal factors released from the gut in response to nutrient ingestion, the incretin hormones. Two major incretin hormones have been characterized, glucagon-like peptide (GLP)-1 and glucose-dependent insulinotropic polypeptide (GIP). GIP is synthesized in K-cells of the upper intestinal tract and released into circulation by the stimulation of K-cells by fat and glucose. GIP facilitates the release of insulin from $\beta$-cells in the presence of postprandial glucose concentrations by activation of its cognate receptor, which is highly expressed on $\beta$-cells and belongs to the family of the G-protein-linked seven transmembrane receptors. Activation of the GIP receptor induces stimulation of the membrane-bound form of adenylate cyclase, which results in the secretion of insulin through an increase in intracellular concentrations of cAMP and calcium. The insulinotropic properties of GIP are responsible for its incretin effect and have been examined in detail (Usdin et al. 1993, Fehmann et al. 1995, Wheeler et al. 1995, Volz et al. 1996, Yip \& Wolfe 2000).

Increasing evidence indicates that GIP may also act physiologically as a growth factor for insulin-producing $\beta$-cells. It was possible to show that GIP could activate mitogenic signaling modules such as mitogen-activated protein kinase (MAPK) and phosphatidylinositol 3-kinase (PI3-kinase) (Straub \& Sharp 1996, Kubota et al. 1997). A knockout of the GIP receptor demonstrated not only a defect in the entero-insular axis, but also a diminished metabolic adaptation of $\beta$-cells under conditions of insulin resistance induced by a high-fat diet (Miyawaki et al. 1999). A recent study demonstrated that a negative dominant overexpression of the human GIP receptor in murine insulin-producing cells results in diminished islet size (Volz-Peters et al. 2000).

We showed previously that GIP acts as a growth factor for the differentiated $\beta$-cell line, INS-1 (Asfari et al. 1992), by pleiotropic activation of the protein kinase A (PKA)/ cAMP regulatory element binder (CREB), MAPK, PI3-kinase/PKB signaling pathways synergistically with glucose (Trümper et al. 2001). These results prompted us to examine whether GIP also acts as an anti-apoptotic factor for the well-differentiated $\beta$-cell line, INS-1. In addition, we determined the mechanisms of mitogenic and anti-apoptotic signaling by GIP and elucidated the nature of cross-talk between signaling pathways by the application of a panel of inhibitors for components of glucose metabolism, $\mathrm{Ca}^{2+}$ signaling and kinases of major signaling modules. Here we show that GIP functions as a mitogenic and anti-apoptotic factor for $\beta$-cells by pleiotropic 


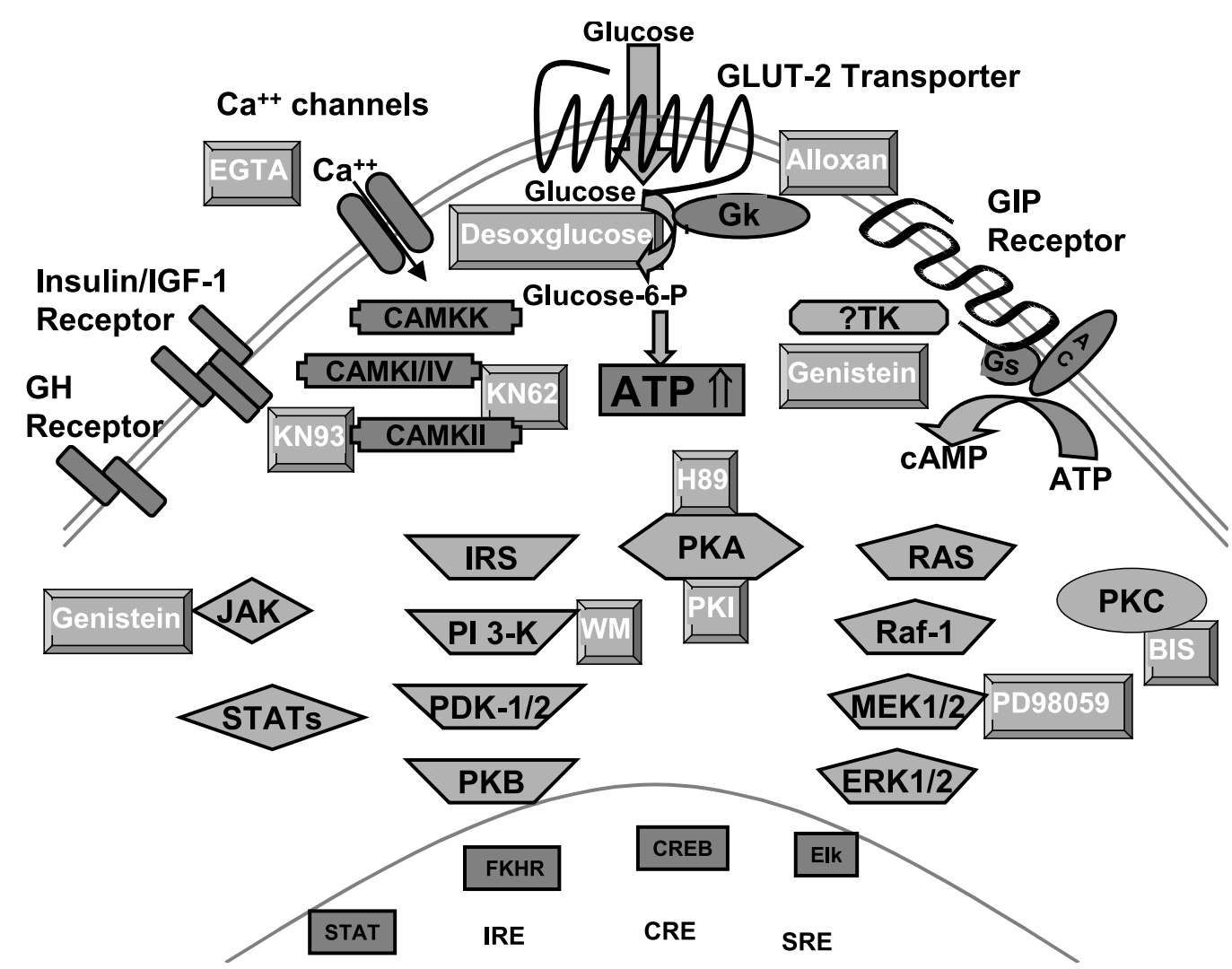

Figure 1 Schematic representation of mitogenic and anti-apoptotic signaling modules and site of action of inhibitors used in this study. AC, membrane-coupled adenylate cyclase; BIS, bisindolylmaleimide I; CAMK, $\mathrm{Ca}^{2+} /$ calmodulin kinase; CAMKK, $\mathrm{Ca}^{2+} /$ calmodulin kinase kinase; CRE, cAMP regulatory element; CREB, CAMP regulatory element binder; Elk, transcription factor Elk; ERK, extracellular-signal related kinase; FKHR, Forkhead transcription factor FKHR; GH, growth hormone; GIP, glucose-dependent insulinotropic polypeptide; Gk, glucokinase; Glucose-6-P, glucose-6-phosphate; GLUT-2, glucose transporter-2; Gs, stimulatory G protein; H89, PKA inhibitor H89; IGF-1, insulin-like growth factor-1; IRE, insulin responsive element; IRS, insulin receptor substrate; JAK, janus kinase; KN62, KN93, CAMK inhibitors KN62, KN93; MEK, MAPK/ERK kinase; PD98059, MEK-1 inhibitor, PD98059; PDK-1/2, phosphoinositide-dependent kinase-1/2; PI 3-K, phosphatidylinositol 3-kinase; PKA, cAMP-dependent protein kinase; PKB, PKC, protein kinases B, C; PKI, protein kinase inhibitor; Raf-1, serine/ threonine kinase raf-1; RAS, small GTPase, cellular protein homologue to $v$-ras; SRE, serum responsive element; STATs, signal transducer and activator of transcription; ?TK, unidentified tyrosine kinase; WM, wortmannin.

activation of PKA/CREB, MAPK and PI3-kinase/PKB, which is highly dependent upon glucose metabolism and $\mathrm{Ca}^{2+}$ influx. Furthermore, we show that activated pathways are tightly interwoven in a network of excitatory and inhibitory cross-talk, which may play a part in the fine-tuned metabolic regulation of $\beta$-cells.

\section{Material and Methods}

\section{Materials}

Silica-gel thin-layer chromatography plates were obtained from Merck (Darmstadt, Germany), protein G agarose was from Santa Cruz Biotechnology (Santa Cruz, CA, USA). Nitrocellulose paper (Optitran BA-S85) was from Schleicher and Schuell (Keene, NH, USA), $\left[\gamma_{-}{ }^{32} \mathrm{P}\right]$ ATP was from Amersham (Munich, Germany). GIP(1-42) was from Bachem (Bubendorf, Switzerland). 5-Bromodeoxyuridine (BrdU) incorporation and cell death detection enzyme-linked immunosorbent assays (ELISAs) were from Roche (Mannheim, Germany). New England Biolabs (Beverly, MA, USA) supplied the PKB $\alpha$ antiserum, 'phospho'-specific antibodies for $\mathrm{Ser}^{473}$ of $\mathrm{PKB} \alpha$ and $\mathrm{Ser}^{133}$ of CREB, along with respective control antibodies for non-phosphorylated kinases, caspase 9 and poly(ADP ribose) polymerase (PARP) antibodies and enhanced chemiluminescence reagents. Antibodies for phosphorylated extracellular-signal regulated kinases (ERK)-1 and -2 (pERK-Tyr ${ }^{204}$ ) and control ERK antibodies were from Santa Cruz Biotechnology. Reagents for SDS-PAGE were from Bio-Rad (Hercules, CA, USA), cell culture reagents from Gibco (Karlsruhe, Germany) and all other chemicals from Sigma (St Louis, MO, USA). 


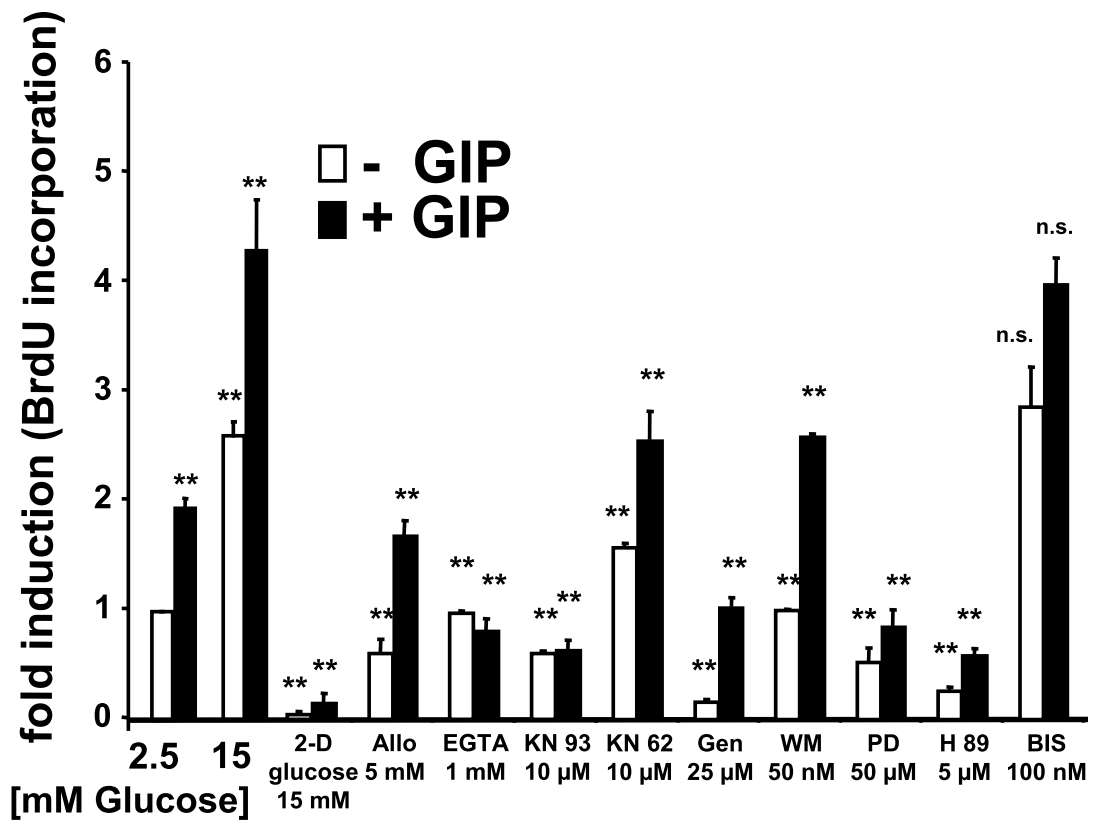

Figure 2 Proliferation and inhibitory profile of INS-1 cells stimulated with a glucose gradient and GIP. INS-1 cells were glucose- and serum-starved overnight and stimulated for $24 \mathrm{~h}$ by $2.5 \mathrm{mM}$ and $15 \mathrm{mM}$ glucose and by $10^{-7} \mathrm{M}$ GIP in the presence of both glucose concentrations. DNA synthesis was measured by the addition of BrdU for the last $6 \mathrm{~h}$ of the stimulation period and subsequent detection by ELISA. Each bar represents the mean \pm S.D. of 12 independent experiments. Values are expressed as relative to control, assigning a value of 1 to cells stimulated with $2.5 \mathrm{mM}$ glucose in the absence of GIP. Inhibitors were added at the beginning of the stimulation, to INS-1 cells stimulated with $15 \mathrm{mM}$ glucose and $10^{-7} \mathrm{M}$ GIP in the presence of $15 \mathrm{mM}$ glucose. Statistical analysis was by ANOVA. ${ }^{*} P<0 \cdot 05$; ${ }^{*} P<0 \cdot 005$; n.s., not significant. 2-D glucose, 2-deoxy-D-glucose; Allo, alloxan; Gen, genistein; WM, wortmannin; PD, PD 98059; BIS: bisindolylmaleimide I.

\section{Inhibitors}

A panel of inhibitors was used to examine the mechanisms of signal transduction by GIP. 2-Deoxy-D-glucose (Sigma) (Lenzen et al. 1988, Isihara \& Wollheim 2000) was used as a non-metabolizable glucose analog and alloxan (Sigma; Lenzen et al. 1988) was used to inhibit glucokinase. EGTA (Sigma) was used as a chelator of $\mathrm{Ca}^{2+}$. The $\mathrm{Ca}^{2+}$ / calmodulin kinase (CAMK) inhibitors KN62 and KN93 (both from Calbiochem-Novabiochem, La Jolla, CA, USA) were used to inhibit preferentially CAMKI/IV and CAMKII (KN62) and, more selectively, CAMKII (KN93) (Marley \& Thomson 1996). Genistein (Davies et al. 2000) was used as a tyrosine kinase inhibitor, wortmannin as a PI3-kinase inhibitor, PD98059 as an MAPK kinase (MEK)-1 inhibitor and bisindolylmaleimide I (Davies et al. 2000) (all from Calbiochem-Novabiochem) as an inhibitor of typical protein kinase $\mathrm{C}$ (PKC) isoforms. For the inhibition of PKA, two different inhibitors were used. For all transfection experiments we used cotransfection of an expression plasmid coding for inhibitory protein kinase (PKI) (Olson \& Uhler 1991) and for all other experiments, H89 (Calbiochem-Novabiochem;
Davies et al. 2000). The site of action of all inhibitors used in this study is summarized in Fig. 1.

\section{Cell culture}

INS-1 cells (passages 80-120) were grown as previously described (Asfari et al. 1992), in regular RPMI-1640 medium supplemented with 10\% FBS, 10 mM HEPES, $1 \mathrm{mM}$ sodium pyruvate, $50 \mu \mathrm{M} \beta$-mercaptoethanol, 100 $\mathrm{IU} / \mathrm{ml}$ penicillin and $100 \mu \mathrm{g} / \mathrm{ml}$ streptomycin at $37^{\circ} \mathrm{C}$ in a humidified $\left(5 \% \mathrm{CO}_{2}, 95 \%\right.$ air) atmosphere. Before stimulation, INS-1 cells were starved in medium without serum, glucose and sodium pyruvate.

\section{BrdU incorporation}

Cells were seeded at a density of $3 \times 10^{6}$ in 96 -well plates, grown for $24 \mathrm{~h}$ in regular medium, washed once with $10 \mathrm{mM}$ PBS (pH 7.4) and subsequently starved for $24 \mathrm{~h}$. They were then incubated for $24 \mathrm{~h}$ in RPMI-medium with different glucose concentrations and test substances. During the last $6 \mathrm{~h}$ of stimulation, $20 \mu \mathrm{l}$ BrdU solution was 


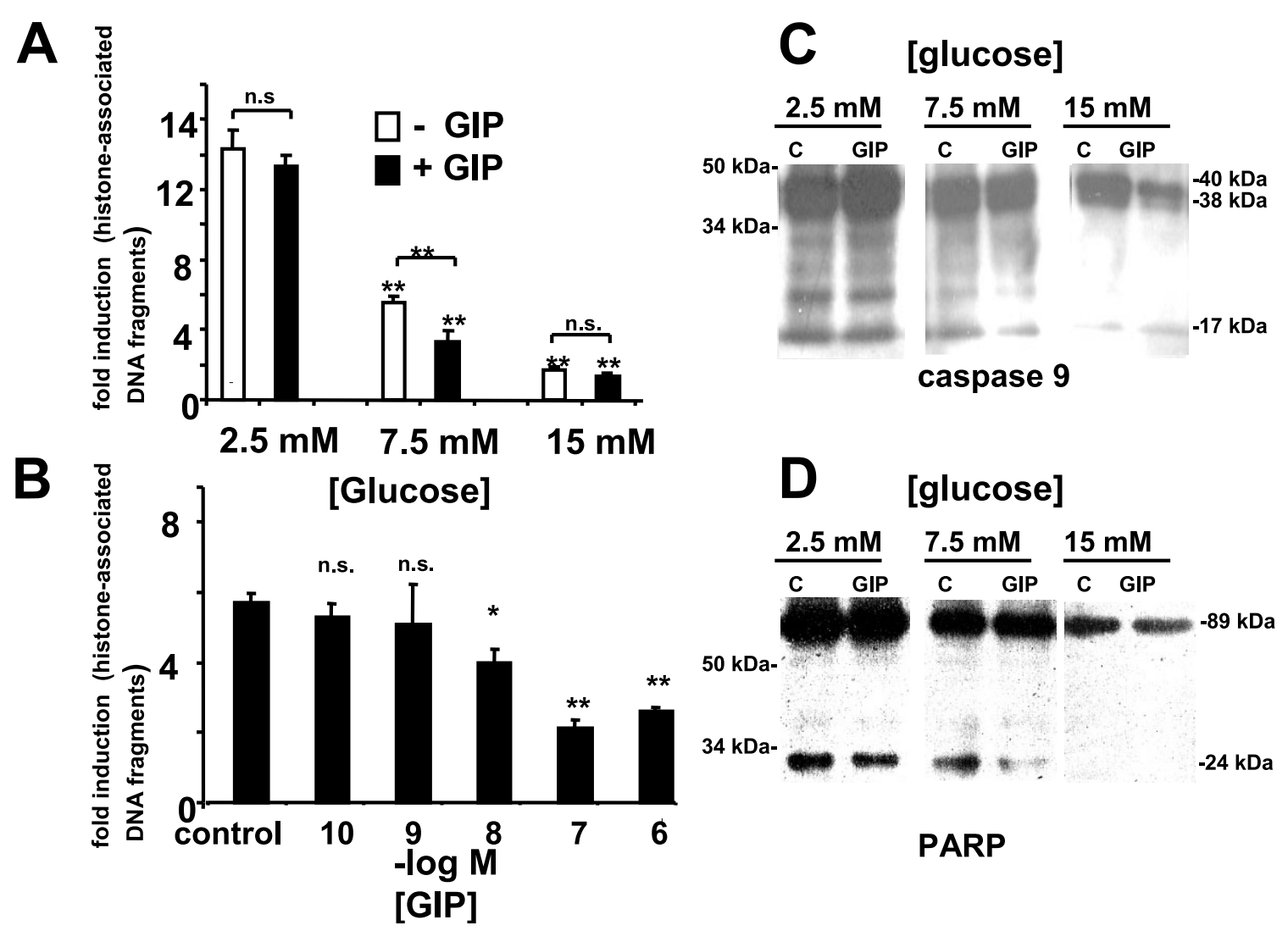

Figure 3 (A) Frequency of apoptosis of serum- and glucose-starved INS-1 cells stimulated by a glucose gradient and GIP. INS- 1 cells were starved overnight and stimulated for $12 \mathrm{~h}$ by $2.5 \mathrm{mM}, 7.5 \mathrm{mM}$ and $15 \mathrm{mM}$ glucose and by $10^{-7} \mathrm{M}$ GIP at all glucose concentrations. Frequency of apoptosis was measured by detection of cytoplasmatic histone-associated DNA fragments. Each bar represents the mean \pm S.D. of six independent experiments. Values are expressed as relative to control, assigning a value of 1 to INS-1 cells cultured with media containing 11.1 mM glucose and 10\% FBS. (B) Dose-response of GIP-induced suppression of apoptosis in the presence of $7.5 \mathrm{mM}$ glucose. The experimental design was as described above, with the exception that graded concentrations of GIP were used with $7.5 \mathrm{mM}$ glucose. Statistical analysis was performed by ANOVA. *P<0.05; ${ }^{*} P<0 \cdot 005$; n.s., non-significant. (C), (D) Prevention of cleavage of caspase 9 (C) and polyADP ribose (PARP) (D) by glucose and GIP. INS-1 cells were stimulated as described in (A), except that immunoblots for the detection of cleaved caspase 9 fragments at $40 \mathrm{kDa}$, $38 \mathrm{kDa}$ and $17 \mathrm{kDa}(\mathrm{C})$ and of PARP fragments at $89 \mathrm{kDa}$ and $24 \mathrm{kDa}(\mathrm{D})$ were performed. C: control.

added and BrdU incorporated into DNA was detected by an ELISA (Huong et al. 1991), which was performed as suggested by the manufacturer.

\section{Apoptosis assay}

To determine the rate of apoptosis, INS-1 cells were grown for $48 \mathrm{~h}$ in 24-well plates, starved for $24 \mathrm{~h}$ and then stimulated with glucose and test substances for $16 \mathrm{~h}$. Cells were lysed, centrifuged and cytoplasmatic histoneassociated DNA fragments were determined in the supernatant by sandwich ELISA (Oehm et al. 1992, Castrillo et al. 2000) as suggested by the manufacturer.

\section{Trans-reporting system for Elk-1 and CREB phosphorylation}

INS-1 cells were grown for $48 \mathrm{~h}$ in normal medium in six-well plates until they reached $60-80 \%$ confluence.
Cells were then washed twice with PBS, transfected with luciferase reporter gene (pFR-Luc) and either Elk-1 (pFA-2-Elk-1) or CREB (pFA-2-CREB) transactivator domains (all from Stratagene, La Jolla, CA, USA) by lipid-based transfection (Pfx-6; Invitrogen, Groningen, Netherlands) for $8 \mathrm{~h}$ in INS-1 medium without serum. Subsequently, cells were grown in INS-1 medium with $5 \mathrm{mM}$ glucose and 5\% FBS and then stimulated for $16 \mathrm{~h}$ in INS-1 medium containing 1\% FBS with GIP at different glucose concentrations. Cells were lysed in luciferase assay buffer (Stratagene) and luciferase activity was determined. For the determination of inhibitory profiles, inhibitors were added at the beginning of the stimulation. In initial experiments, we cotransfected an expression vector harboring the $\beta$-galactosidase gene under the control of the cytomegalovirus promoter and assayed cell lysates for $\beta$-galactosidase activity as an internal control for 


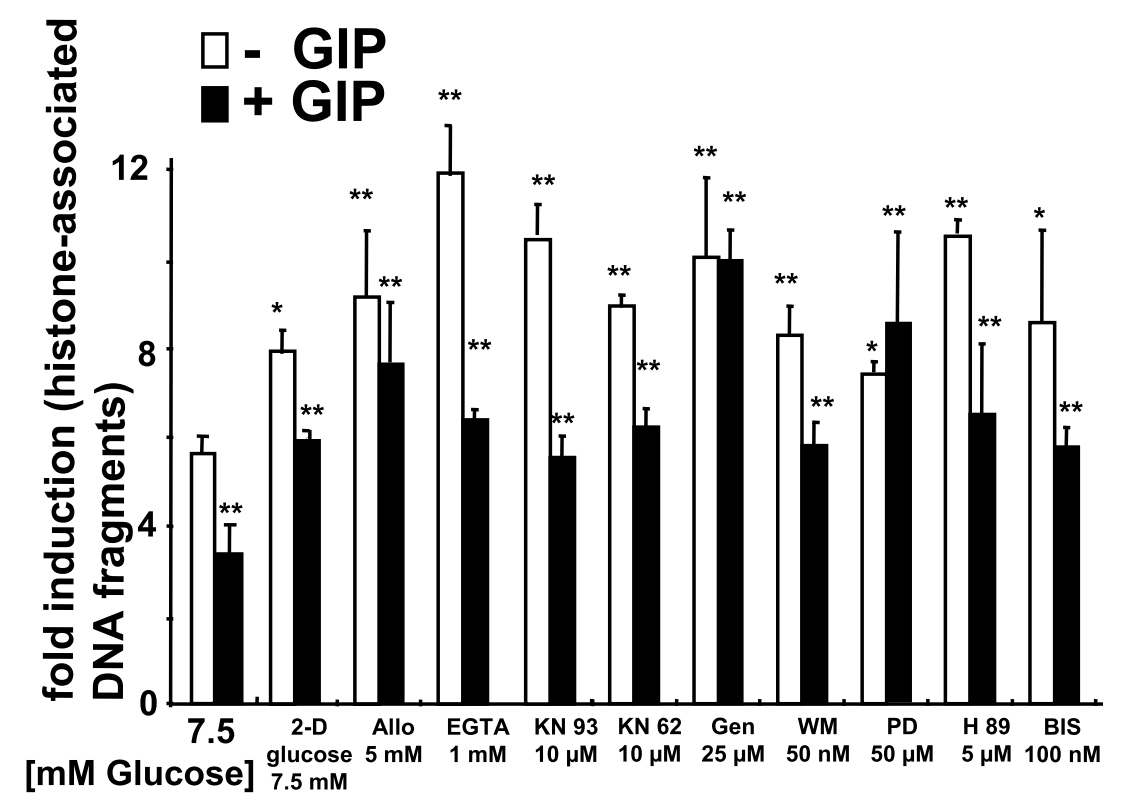

Figure 4 Frequency of apoptosis in INS-1 cells treated with inhibitors and stimulated by $7.5 \mathrm{mM}$ glucose and by $10^{-7} \mathrm{M}$ GIP in the presence of $7.5 \mathrm{mM}$ glucose. Cells were stimulated as described above and the frequency of apoptosis was measured by detection of cytoplasmatic histone-associated DNA fragments. Inhibitors were added at the beginning of the stimulation. Each bar represents the mean \pm S.D. of six independent experiments. Values are expressed as relative to control, assigning a value of 1 to INS-1 cells cultured with media containing $11.1 \mathrm{mM}$ glucose and $10 \%$ FBS. Statistical analysis was performed by ANOVA. ${ }^{*} P<0 \cdot 05 ;{ }^{*} P<0 \cdot 005$. Abbreviations as in Fig. 2.

non-specific changes in transcription. Statistical analysis was performed by analysis of variance (ANOVA).

\section{Immunoblotting}

INS-1 cells were starved for $12 \mathrm{~h}$ and were then equilibrated for another $12 \mathrm{~h}$ in indicated glucose concentrations. One hour before the stimulation, the medium was changed. When inhibitors were used, they were added 10 min before stimulation with GIP. Cells were lysed after stimulation in ice-cold lysis buffer (1\% Triton X-100, 10\% glycerol, $50 \mathrm{mM}$ Hepes $\mathrm{pH} 7 \cdot 4,100 \mathrm{mM}$ sodium pyrophosphate, $100 \mathrm{mM}$ sodium fluoride, $10 \mathrm{mM}$ EDTA, $5 \mathrm{mM}$ sodium vanadate, $10 \mu \mathrm{g} / \mathrm{ml}$ aprotinin, $5 \mu \mathrm{g} / \mathrm{ml}$ leupeptin, $1.5 \mathrm{mg} / \mathrm{ml}$ benzamidine, and $34 \mu \mathrm{g} / \mathrm{ml}$ phenyl methylsulphonyl fluoride), sonicated for $15 \mathrm{~s}$ and insoluble material was removed by centrifugation at 15000 r.p.m. in a microfuge for $10 \mathrm{~min}$. For immunoblotting, $100 \mu \mathrm{g}$ protein per lane were separated by 10\% SDS-PAGE, Western transferred onto nitrocellulose membranes and probed as described previously (Kerouz et al. 1997). Protein bands were visualized with enhanced chemiluminescence. Autoradiographs were scanned and band density was determined using Gelscan 3D software (BioSciTec, Marburg, Germany).

\section{Results}

\section{Mitogenic effects of GIP and glucose}

Proliferation of INS-1 cells was determined as the rate of DNA synthesis, by enzyme-linked detection of BrdU incorporation. BrdU incorporation in the presence of $2.5 \mathrm{mM}$ glucose without GIP served as control and was set at 1 . An increase in glucose concentration to $15 \mathrm{mM}$ induced a significant increase in proliferation $(2 \cdot 8 \pm 0 \cdot 14$ fold (mean \pm S.D.) control; $n=12$; Fig. 2). Additional stimulation with $10^{-7} \mathrm{M}$ GIP instigated an approximately twofold increase in INS-1 cell proliferation at both low and high glucose concentrations. In subsequent experiments, a panel of inhibitors (Fig. 1) was applied to INS-1 cells stimulated with $15 \mathrm{mM}$ glucose and with $10^{-7} \mathrm{M}$ GIP in the presence of $15 \mathrm{mM}$ glucose to elucidate the mechanisms of proliferation induced by glucose and GIP (Fig. 2). Glucose-induced proliferation was prevented by inhibition of glucose metabolism, $\mathrm{Ca}^{2+}$ influx, tyrosine kinases, PKA, MEK-1/2, and PI3-kinase. Inhibition of CAMKII by KN93 induced a more effective reduction in glucose-induced INS-1 cell proliferation than did inhibition of CAMK isoforms I/IV and II by KN62. The inhibitory profile of GIP-induced proliferation of INS-1 cells was similar to that of glucose-stimulated cells. 


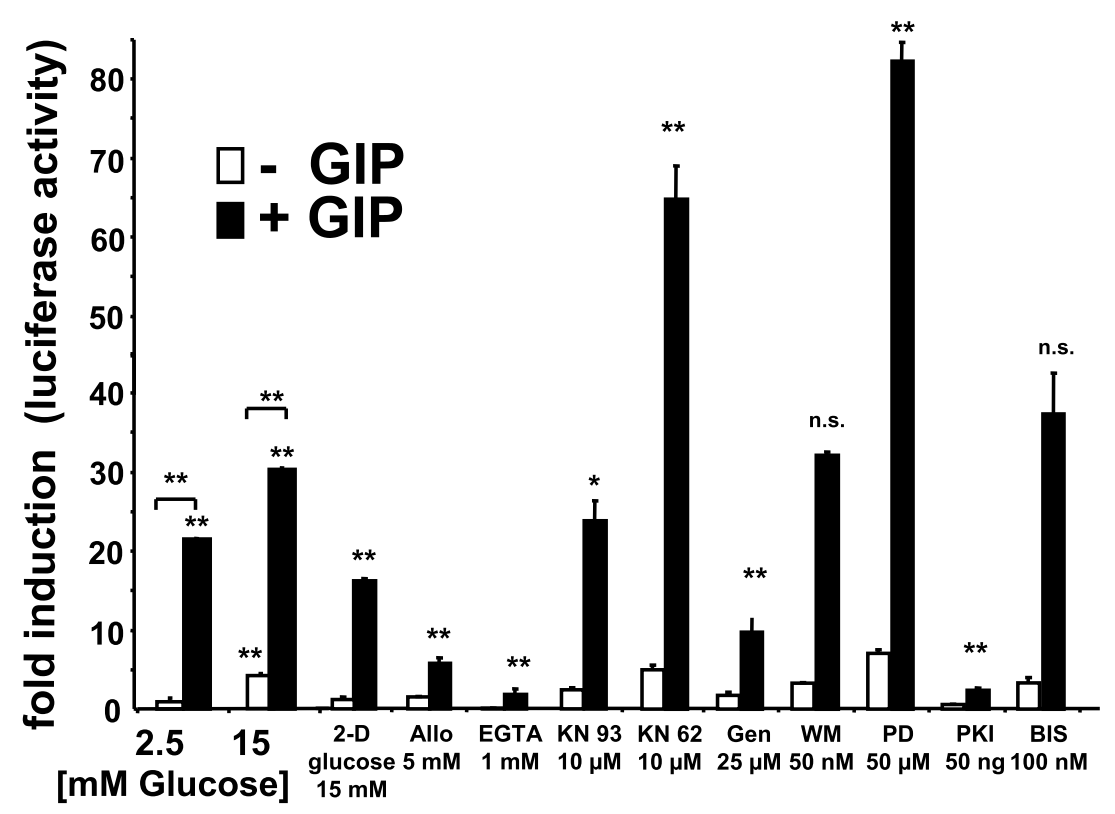

Figure 5 Inhibitory profile of the PKA/CREB signaling module activated by GIP and glucose. INS-1 cells were transfected with a CREB transactivator plasmid as described in Material and Methods. The cells were stimulated for $16 \mathrm{~h}$ by $2.5 \mathrm{mM}$ or $15 \mathrm{mM}$ glucose and by $10^{-7} \mathrm{M}$ GIP with both glucose concentrations. CREB phosphorylation was determined by the luciferase activity of a cotransfected reporter plasmid. The luciferase activity of INS-1 cells stimulated by $2.5 \mathrm{mM}$ glucose without GIP served as control and was set at 1 . Inhibitors were added at the beginning of the stimulation, to INS-1 cells stimulated by $15 \mathrm{mM}$ glucose and by $10^{-7} \mathrm{M}$ GIP in the presence of $15 \mathrm{mM}$ glucose. Each bar represents the mean \pm S.D. of four or five independent experiments. Statistical analysis was performed by ANOVA. ${ }^{*} P<0 \cdot 05 ;{ }^{*} P<0 \cdot 005$. Abbreviations as in Fig. 2.

However, some differences were noted: GIP-induced proliferation was less dependent upon glucokinase activity, tyrosine kinases and PI3-kinase, and more dependent upon $\mathrm{Ca}^{2+}$ influx and signaling. Inhibition of PKC isoforms by bisindolylmaleimide I did not affect glucose- and GIP-stimulated INS-1 cell proliferation (Figs 1 and 2).

\section{Anti-apoptotic effects of GIP and glucose}

To determine whether GIP and glucose act as antiapoptotic factors for $\beta$-cells, frequency of apoptosis of serum-starved INS-1 cells in the presence of different glucose concentrations was determined by enzyme-linked detection of cytosolic histone-associated DNA fragments (Castrillo et al. 2000). Frequency of apoptosis under normal culture conditions served as a control and was set at 1 . In the presence of $2.5 \mathrm{mM}$ glucose, frequency of apoptosis was highly increased (14-fold) as compared with control, and the addition of $10^{-7} \mathrm{M}$ GIP showed only a minimal effect, suppressing the rate of apoptosis to 13-fold (Fig. 3A). The addition of $7.5 \mathrm{mM}$ glucose inhibited the frequency of apoptosis significantly, to $5 \cdot 5$-fold compared with $2.5 \mathrm{mM}$ glucose. In the presence of $7.5 \mathrm{mM}$ glucose, additional stimulation of INS-1 cells with $10^{-7} \mathrm{M}$ GIP led to further statistically significant inhibition of the frequency of apoptosis, to 3-3-fold. With $15 \mathrm{mM}$ glucose, frequency of apoptosis was close to control, with a $1 \cdot 6$-fold increase, and was only slightly additionally inhibited, to 1.3-fold, by $10^{-7} \mathrm{M}$ GIP (Fig. 3A). No further reduction in the rate of apoptosis was observed with $20 \mathrm{mM}$ and $25 \mathrm{mM}$ glucose (data not shown). As we could show that the suppression of apoptosis by GIP was most effective with $7 \cdot 5 \mathrm{mM}$ glucose, we chose this glucose concentration for the elucidation of the dose-response curve of GIPinduced suppression of apoptosis (Fig. 3B). Frequency of apoptosis was suppressed by GIP at concentrations between $10^{-8}$ and $10^{-6} \mathrm{M}$ GIP, whereas lower concentrations of GIP were not effective (Fig. 3B). In the course of apoptosis, cleavage of caspase 9 and PARP occurs before the cytoplasmatic liberation of histone-associated DNA fragments. We therefore examined the effect of glucose and GIP on caspase 9 and PARP cleavage in serum- and glucose-starved INS-1 cells by immunoblot detection of cleaved fragments of both molecules (Fig. 3C and D). Here, glucose and GIP prevented cleavage of caspase 9 and PARP synergistically in a manner similar to the inhibition of cytoplasmatic liberation of histone-associated DNA fragments (Fig. 3C and D).

The same panel of inhibitors as in previous experiments was used to examine signaling pathways involved in the 


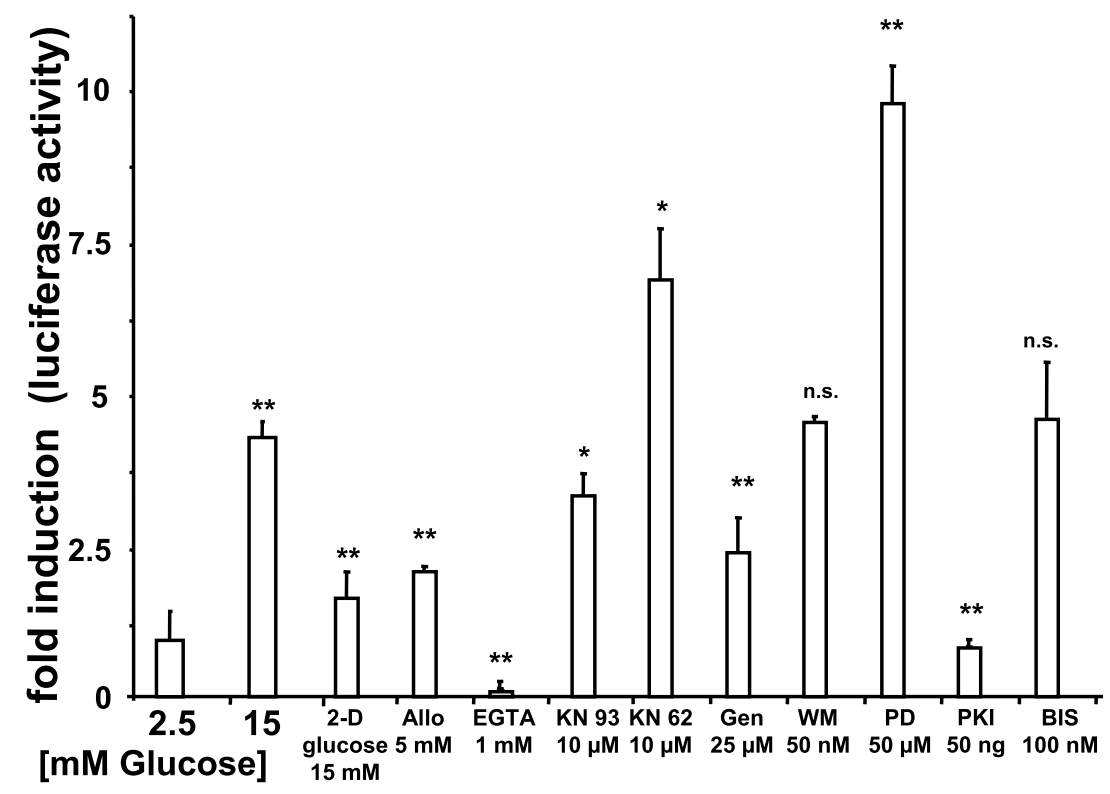

Figure 6 Detail of Fig. 5, depicting inhibitory profile of PKA/CREB activated by glucose, on an enlarged scale. Experimental design and statistical analysis as in Fig. 5.

inhibition of apoptosis by glucose and GIP. Inhibitors were added to INS-1 cells stimulated with $7.5 \mathrm{mM}$ glucose and $10^{-7} \mathrm{M}$ GIP with $7 \cdot 5 \mathrm{mM}$ glucose (Fig. 4). The strongest inducer of apoptosis in glucose-stimulated cells was EGTA, followed by KN93 $10 \mu \mathrm{M}$, genistein, H89 and alloxan; other inhibitors were less effective (Fig. 4). A potent role of the MAPK-inhibitor PD98059 and genistein was noted for the inhibitory profile of apoptosis prevented by GIP in the presence of $7.5 \mathrm{mM}$ glucose. Although the PKC inhibitor bisindolylmaleimide I had no effect upon glucose- and GIP-induced INS-1 cell proliferation (Fig. 2), it slightly increased the rate of apoptosis in INS-1 cells stimulated with glucose and GIP (Fig. 4).

\section{Activation of PKA/CREB by GIP and glucose}

Activation of the PKA/CREB signaling module was measured by phosphorylation of CREB in a transactivation assay using luciferase as a reporter gene (Figs 5 and 6). CREB phosphorylation in the presence of $2.5 \mathrm{mM}$ glucose served as control and was set at 1 . Basal concentrations of CREB phosphorylation were increased to almost fivefold in the presence of $15 \mathrm{mM}$ glucose. With $2.5 \mathrm{mM}$ glucose, $10^{-7} \mathrm{M}$ GIP instigated a 21-fold increase in CREB phosphorylation, which was further increased by $15 \mathrm{mM}$ glucose (Figs 5 and 6). To examine the pathways of GIP- and glucose-stimulated CREB phosphorylation, we used the same set of inhibitors as for the proliferation and apoptosis assays in the CREB-transactivating luciferase assay, except that H89 was replaced by cotransfection of PKI for the inhibition of PKA. Figure 5 depicts the effects of inhibitors on CREB phosphorylation of glucose and GIP-stimulated INS-1 cells; the effect of inhibitors on glucose-induced CREB phosphorylation is magnified in Fig. 6 on a different scale. Inhibition of glucose metabolism and calcium influx, and PKA inhibition by PKI and tyrosine kinase inhibition by genistein, prevented glucose- and GIP-stimulated CREB phosphorylation (Figs 5 and 6). Wortmannin and bisindolylmaleimide I had no significant effect on CREB phosphorylation. KN93, which preferentially inhibits CAMKII, exerted only a minor reduction in glucose- and GIP-induced CREB phosphorylation. However, the CAMKI/IV and CAMKII inhibitor KN62, in addition to the MEK-1 inhibitor PD98059, augmented glucose- and, especially, GIP-stimulated CREB phosphorylation, indicating an inhibitory influence of CAMKI/IV and MEK-1 upon the PKA/CREB pathway (Figs 1 and 5-7). As a stimulation of $16 \mathrm{~h}$ was needed in the transactivating luciferase assay, it could not be excluded that the inhibitors used exerted a toxic influence upon the INS-1 cells, interfering with signal transduction. We therefore corroborated our results by stimulating the cells overnight with glucose and with GIP for $60 \mathrm{~min}$. The same panel of inhibitors as for the transactivating luciferase assay was applied $60 \mathrm{~min}$ before harvesting of the cells, and subsequently CREB phosphorylation was examined by immunoblotting. This approach had the advantage of a shorter stimulation and inhibition. Generally, we found a similar pattern of inhibition for glucose- and GIP-induced CREB phosphorylation in the immunoblot analysis compared with the transactivation assays. However, some subtle differences were noted. Replacing cotransfection of PKI by H89 resulted in a less effective inhibition of CREB 


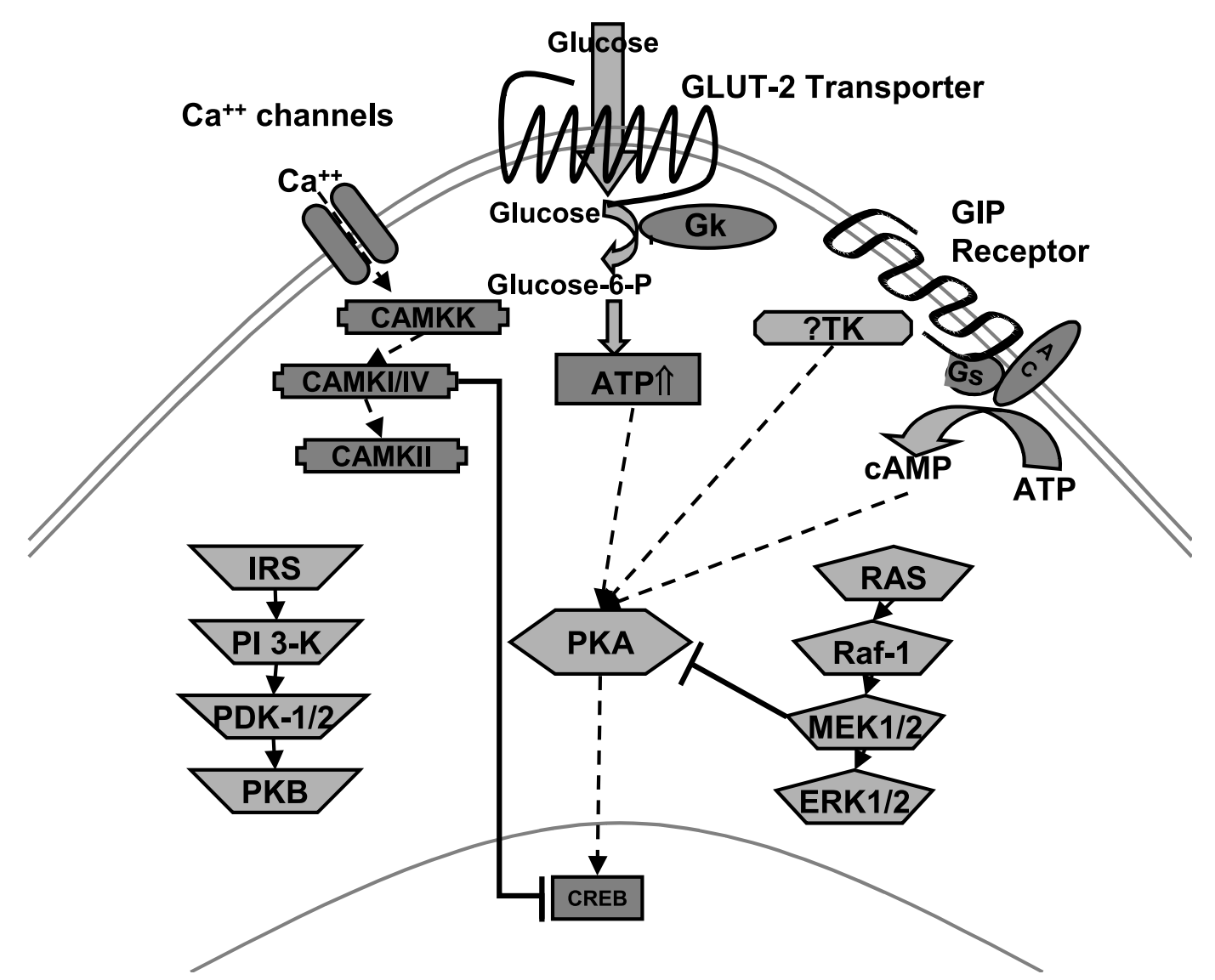

Figure 7 Schematic representation of mechanisms of PKA/CREB stimulation by GIP and glucose in pancreatic $\beta$-cells. Abbreviations as in Fig. 1.

phosphorylation $(0 \cdot 6$-fold for glucose and $0 \cdot 7$-fold for GIP compared with respective controls; typical result of $n=3$; data not shown). We also examined the inhibitory effect of selected inhibitors at different glucose and GIP concentrations and found inhibition patterns similar to the results shown in Fig. 6 (data not shown). The pathways leading to PKA/CREB activation by glucose and GIP are summarized in Fig. 7.

\section{Activation of MAPK by GIP and glucose}

Activation of the MAPK pathway signaling module was examined by phosphorylation of the transcription factor Elk-1 in a transactivation assay using luciferase as a reporter gene (Fig. 8). Elk-1 phosphorylation in the presence of $2.5 \mathrm{mM}$ glucose served as control and was set at 1 . Glucose $15 \mathrm{mM}$ stimulated Elk-1 phosphorylation 4.6-fold. With $2.5 \mathrm{mM}$ glucose, $10^{-7} \mathrm{M}$ GIP induced a 10 -fold increase in Elk-1 phosphorylation, which was further increased to 17 -fold in the presence of $15 \mathrm{mM}$ glucose. We used the Elk-1-transactivating luciferase assay to determine the influence of inhibitors on MAPK activation. Glucose- and GIP-stimulated Elk-1 phosphorylation were inhibited by the blockade of glucose metabolism, $\mathrm{Ca}^{2+}$ influx, CAMK activation, tyrosine kinases, PI3-kinase and PKA, whereas PKC inhibition had no effect (Figs 8 and 9). The MEK-1 inhibitor PD98059 showed a stronger effect on GIinduced Elk-1 phosphorylation than on stimulation by glucose alone (Fig. 8), which was also the case for the glucokinase inhibitor, alloxan. These results were verified in immunoblotting experiments for the MAPK kinases ERK-1/2 using the same panel of inhibitors as described above. Here, we were able to show a similar pattern of inhibition, with the exception that the application of $10 \mu \mathrm{M}$ KN93 yielded a less effective inhibition $(0 \cdot 7$-fold compared with control; typical blot of $n=3$; data not shown) than did the transactivating luciferase assay for Elk-1 phosphorylation. Pathways of MAPK activation by GIP and glucose are summarized in Fig. 9.

\section{Activation of PKB by GIP and glucose}

Previously, we showed that activation of PKB by GIP and glucose occurs via the insulin receptor substrate isoforms IRS-2 and Gab-1 and the PI3-kinase regulatory isoform $\mathrm{p} 85 \alpha$, in addition to the catalytic isoforms $\mathrm{p} 110 \alpha, \mathrm{p} 110 \beta$ 


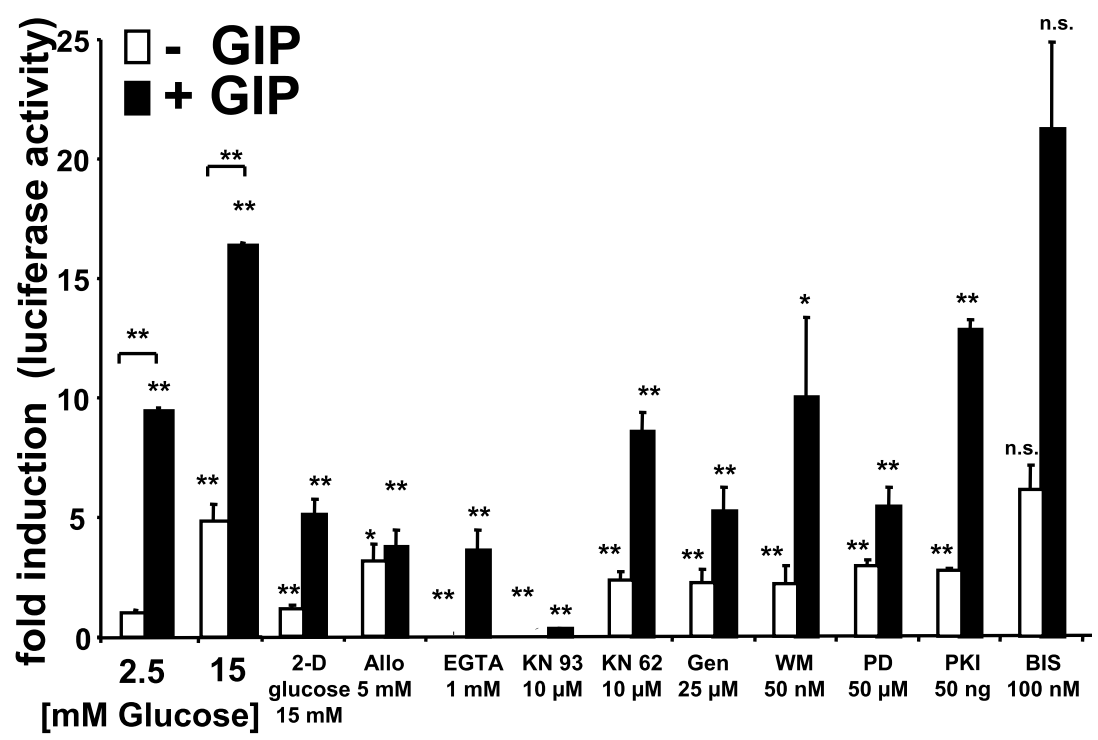

Figure 8 Inhibitory profile of the MAPK signaling module activated by glucose and GIP at the level of the transcription factor Elk-1. INS-1 cells were transfected with an Elk-1 transactivator plasmid as described in Material and Methods. The cells were stimulated for $16 \mathrm{~h}$ by $2.5 \mathrm{mM}$ or $15 \mathrm{mM}$ glucose and by $10^{-7} \mathrm{M}$ GIP with both glucose concentrations. Elk-1 phosphorylation was determined by the luciferase activity of a cotransfected reporter plasmid. The luciferase activity of INS-1 cells stimulated by $2.5 \mathrm{mM}$ glucose without GIP served as control, and was set at 1 . Inhibitors were added, at the beginning of the stimulation, to INS-1 cells stimulated by $15 \mathrm{mM}$ glucose and by $10^{-7} \mathrm{M}$ GIP with $15 \mathrm{mM}$ glucose. Each bar represents the mean \pm S.D. of four or five independent experiments. Statistical analysis was performed by ANOVA. ${ }^{*} P<0 \cdot 05 ;{ }^{* *} P<0 \cdot 005$. Abbreviations as in Fig. 2.

and $\mathrm{p} 110 \gamma$ (Fig. 11). PKB activation was detected by immunoblotting INS-1 cell lysates with an activationspecific antibody for pPKBSer ${ }^{473}$. Basal PKB phosphorylation increased $4 \cdot 5$-fold with increasing glucose concentrations from $2.5 \mathrm{mM}$ to $15 \mathrm{mM}$. The addition of $10^{-7} \mathrm{M}$ GIP instigated a further increase in PKB phosphorylation (Fig. 10). To map the pathways leading to $\mathrm{PKB}$ phosphorylation, we applied the same set of inhibitors as in the previous experiments and examined PKB phosphorylation by glucose at $15 \mathrm{mM}$ and by $10^{-7} \mathrm{M}$ GIP with $15 \mathrm{mM}$ glucose. The experimental design was as described above. Glucose-induced PKB phosphorylation was inhibited preferentially by blocking glucose metabolism and $\mathrm{Ca}^{2+}$ influx/signaling and also PKA, whereas inhibition of tyrosine kinases, PI3-kinase and MEK-1 was less effective (Figs 10 and 11). GIPstimulated PKB phosphorylation was dependent upon glucose metabolism and MEK-1 activation, whereas inhibition of $\mathrm{Ca}^{2+}$ influx and CAMK had only a marginal effect (Figs 10 and 11). Genistein and wortmannin almost completely blocked PKB phosphorylation by GIP, indicating an activating involvement of tyrosine kinases and PI3-kinase. Inhibition of PKA by H89 decreased GIPinduced PKB phosphorylation to a lesser degree than the inhibition observed for glucose-stimulated PKB activation (Figs 10 and 11). Bisindolylmaleimide I had no significant effect on glucose- and GIP-stimulated PKB phosphorylation. Pathways of PI3-kinase/PKB activation by glucose and GIP are summarized in Fig. 11.

\section{Discussion}

The differentiation, mass and function of insulin-secreting $\beta$-cells of the pancreas are regulated by several $\beta$-cell growth-factors (Rane \& Reddy 2000, Nielsen et al. 2001, Porte \& Kahn 2001, Weir et al. 2001). Recently, we demonstrated that the incretin hormone, GIP, is a growth factor for $\beta$-cells, by pleiotropic activation of mitogenic signaling modules (Trümper et al. 2001). Here, we have shown that, in addition, GIP and glucose act synergistically as anti-apoptotic factors for the well-differentiated $\beta$-cell line, INS-1. In contrast to synergistic mitogenic effects of glucose and GIP over a broad range of glucose concentrations (Fig. 2), anti-apoptotic synergism between GIP and glucose was restricted to medium concentrations of glucose. It has been shown that glucose metabolism and apoptosis are closely linked in a number of cell types, by the apoptotic effect of glucose-starvation-induced depletion of intracellular ATP (Moley \& Mueckler 2000). Using the non-metabolizable glucose-analog, 2-deoxy-Dglucose, and the glucokinase inhibitor, alloxan, we demonstrated that glucose metabolism and glucokinase activity 


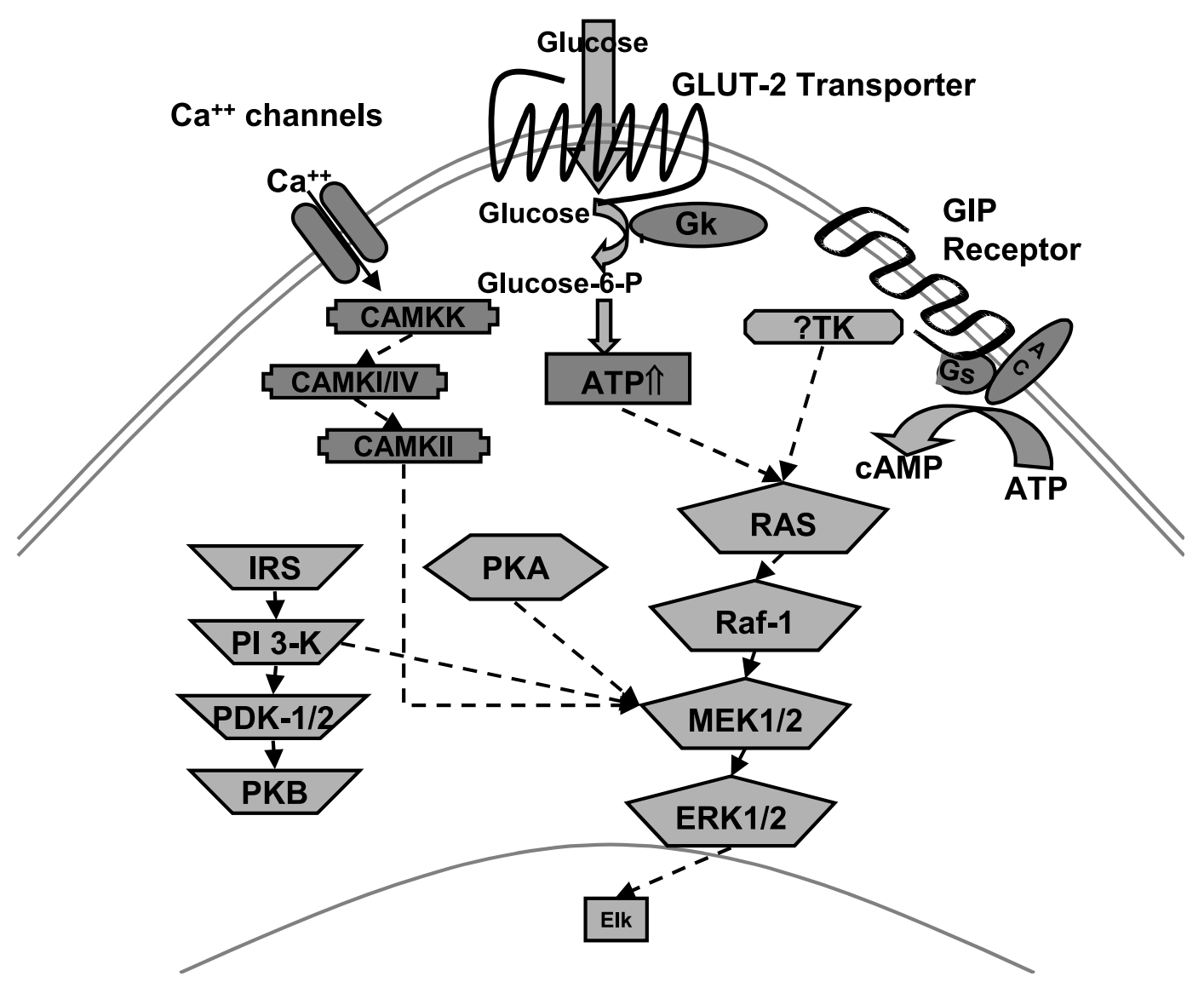

Figure 9 Schematic representation of the mechanisms of MAPK stimulation by GIP and glucose in pancreatic $\beta$-cells. Abbreviations as in Fig. 1.

are involved in the generation of anti-apoptotic signals from glucose. Whether anti-apoptotic signaling by glucose is mediated by an altered ADP:ATP ratio, by glutamine or by glucokinase signaling (Isihara \& Wollheim 2000, Moley \& Mueckler 2000, Ronner et al. 2001) remains to be elucidated. It seems likely that the availability of ATP in cytosolic compartments may be the decisive factor for the kinase activity of anti-apoptotic signaling cascades, which may imitate a second messenger effect. The application of a well-characterized set of inhibitors (Figs 1 and 3) revealed that the anti-apoptotic action of GIP and glucose required pleiotropic activation of glucose metabolism, $\mathrm{Ca}^{2+}$ signaling and the signaling modules of PKA/CREB, MAPK and PI3-kinase. These results indicate that mitogenic and anti-apoptotic signaling by GIP and glucose require activation of similar pathways, with the exception of PKC. Inhibition of PKC by bisindolylmaleimide I had no significant effect on GIP- and glucose-induced proliferation of INS-1 cells, whereas it increased the rate of apoptosis in GIP and glucose-stimulated INS-1 cells (Figs 2 and 4).

$\mathrm{Ca}^{2+}$ signaling has a central role in insulinotropic (Fehmann et al. 1995, Yip \& Wolfe 2000) and mitogenic signaling in $\beta$-cells (Frödin et al. 1998, this study). Inhibition of $\mathrm{Ca}^{2+} /$ calmodulin kinases (CAMK) by KN62 or KN93 and blockade of $\mathrm{Ca}^{2+}$ influx by EGTA have been shown to interfere with glucose-induced insulin release (Fehmann et al. 1995, Marley \& Thomson 1996). In our study, we demonstrated a central role of $\mathrm{Ca}^{2+}$ influx and CAMKs in the regulation of mitogenic and anti-apoptotic signal transduction by glucose and GIP. By blocking $\mathrm{Ca}^{2+}$ influx with EGTA, proliferation of INS-1 cells was inhibited, the rate of apoptosis was increased, and glucoseand GIP-stimulated PKA/CREB and MAPK pathways were inhibited. Furthermore, PKB activation by glucose was inhibited, whereas GIP-induced PKB phosphorylation was unaffected. To inhibit the different CAMKs expressed in $\beta$-cells, we used KN62 and KN93. KN62, which preferentially inhibits CAMK isoforms I/IV and II, exhibited a similar inhibitory profile as EGTA, albeit at a lower level of inhibition. KN93, which is reportedly a more selective inhibitor for CAMKII ( $\mathrm{Li}$ et al. 1992, Marley \& Thomson 1996), inhibited proliferation and MAPK activation more efficiently than did KN62. These results indicate that $\mathrm{Ca}^{2+}$ influx and signaling by different CAMK isoforms is an essential component of mitogenic 


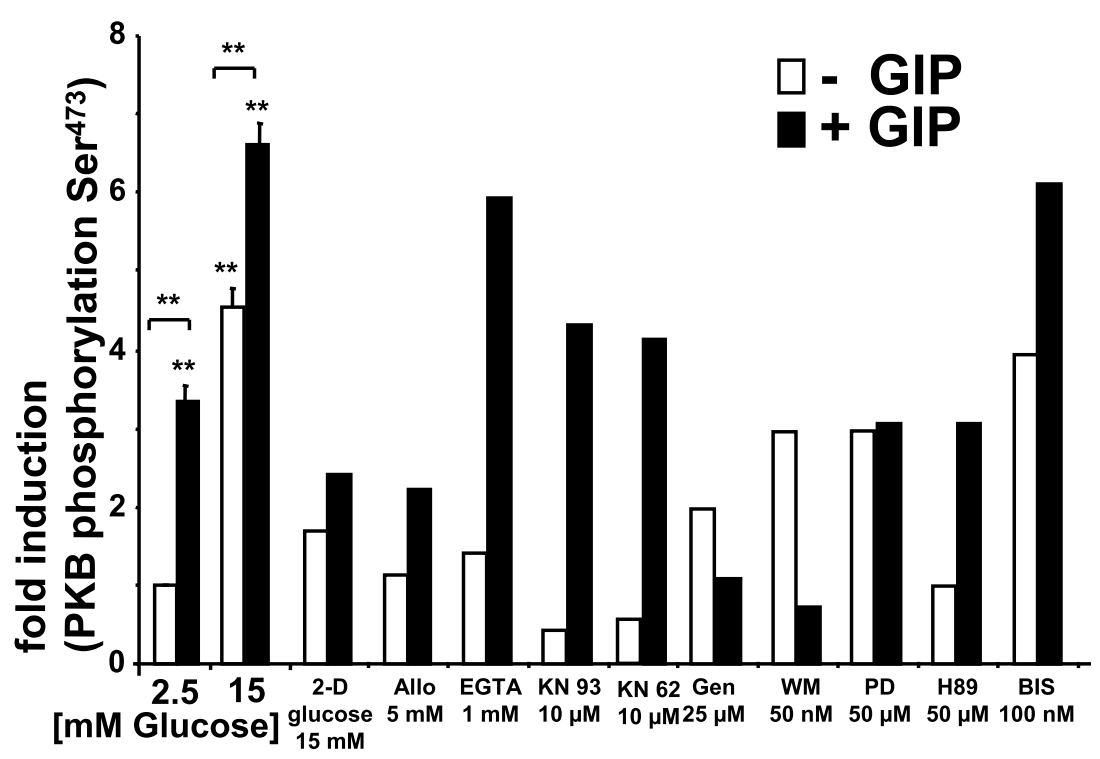

Figure 10 Activation and inhibitory profile of PKB activation by GIP and glucose. INS-1 cells were serum-starved overnight in the presence of low $(2.5 \mathrm{mM})$ and high $(15 \mathrm{mM})$ concentrations of glucose and subsequently stimulated for $60 \mathrm{~min}$ by $10^{-7} \mathrm{M}$ GIP at both glucose concentrations. Cells were lysed and $100 \mu \mathrm{g}$ protein was separated by SDS-PAGE and Western immunoblotted. The degree of PKB phosphorylation was determined using activation-specific antibody for $\mathrm{pSer}^{473} \mathrm{PKB} \alpha$ as described in Methods. Immunoblots using an antiserum recognizing total PKB $\alpha$ served as a control for equal loading (not shown). Proteins were detected using enhanced chemiluminescence, and band densities were quantified by densitometry. Data are the mean \pm S.E.M. of $6-10$ independent experiments for the activation data and represent typical blots of $n=3$ for the inhibitory profile. Statistical analysis was performed by ANOVA. ${ }^{\star} P<0 \cdot 05 ;{ }^{*} P<0 \cdot 005$. Inhibitors were added 10 min before stimulation. Abbreviations as in Fig. 2.

and anti-apoptotic signaling by glucose and GIP in INS-1 cells via the activation of signaling pathways. However, distinct CAMK isoforms exert a differential role in activation of PKA/CREB by GIP and glucose. Although, PKA/CREB activation by glucose and GIP was prevented by EGTA, KN62 enhanced glucose- and GIP-stimulated CREB phosphorylation, whereas KN93 was a minor inhibitor. These results indicate that CAMKI/IV exert an inhibitory influence on the PKA/CREB signaling module, which has been shown in other cell models to occur by phosphorylation at $\operatorname{Ser}^{142}$ of CREB (Sun et al. 1996).

The major mitogenic and anti-apoptotic signaling modules such as the PKA/CREB, MAPK, PI3-kinase/PKB and JAK/STAT pathways are widely expressed, and may be activated by different kinds of receptors and also coactivated by pleiotropic signaling. Thus, in distinct cell types, specificity of signal transduction is maintained, among other factors, by cross-talk between activated signaling cascades and cell-specific sets of kinase isoforms (Pawson \& Saxton 1999, Simon 2000). To elucidate the mechanisms of signal transduction by glucose and GIP in $\beta$-cells, we applied a panel of inhibitors to stimulated signaling pathways and found numerous sites of cross-talk between signaling cascades. We demonstrated: (i) a central role of tyrosine phosphorylation for stimulation of PKA/ CREB, MAPK and PI3-kinase/PKB, (ii) inhibition of PKA/CREB by the MAPK pathway at the level of MEK-1 or downstream, (iii) activation of MAPK signaling by PI3-kinase and PKA at the level of ERK1/2 or upstream, and (iv) activation of PKB by MAPK and PKA signaling at the level of $\mathrm{PKB}$ or upstream. For detection of proliferation, apoptosis and CREB/Elk-1 phosphorylation in the transactivating luciferase assay, inhibitors were applied between 12 and $24 \mathrm{~h}$, raising the question of whether inhibitory effects were caused by specific interaction or a general toxic effect. We therefore re-examined PKA/CREB and MAPK activation by glucose and GIP by applying inhibitors for $60 \mathrm{~min}$ only before the assays, and achieved similar results (data not shown). Furthermore, we applied selected inhibitors in the presence of different glucose and GIP concentrations and found that the inhibitory effects were similar (data not shown). Although these experiments indicated that the inhibitory effects demonstrated in our study are caused by specific interaction rather than by general toxic effects, the question of the specificity of inhibitor-kinase interactions remains. In a recent systematic study, Davies et al. (2000) showed that commonly used protein kinase inhibitors are 


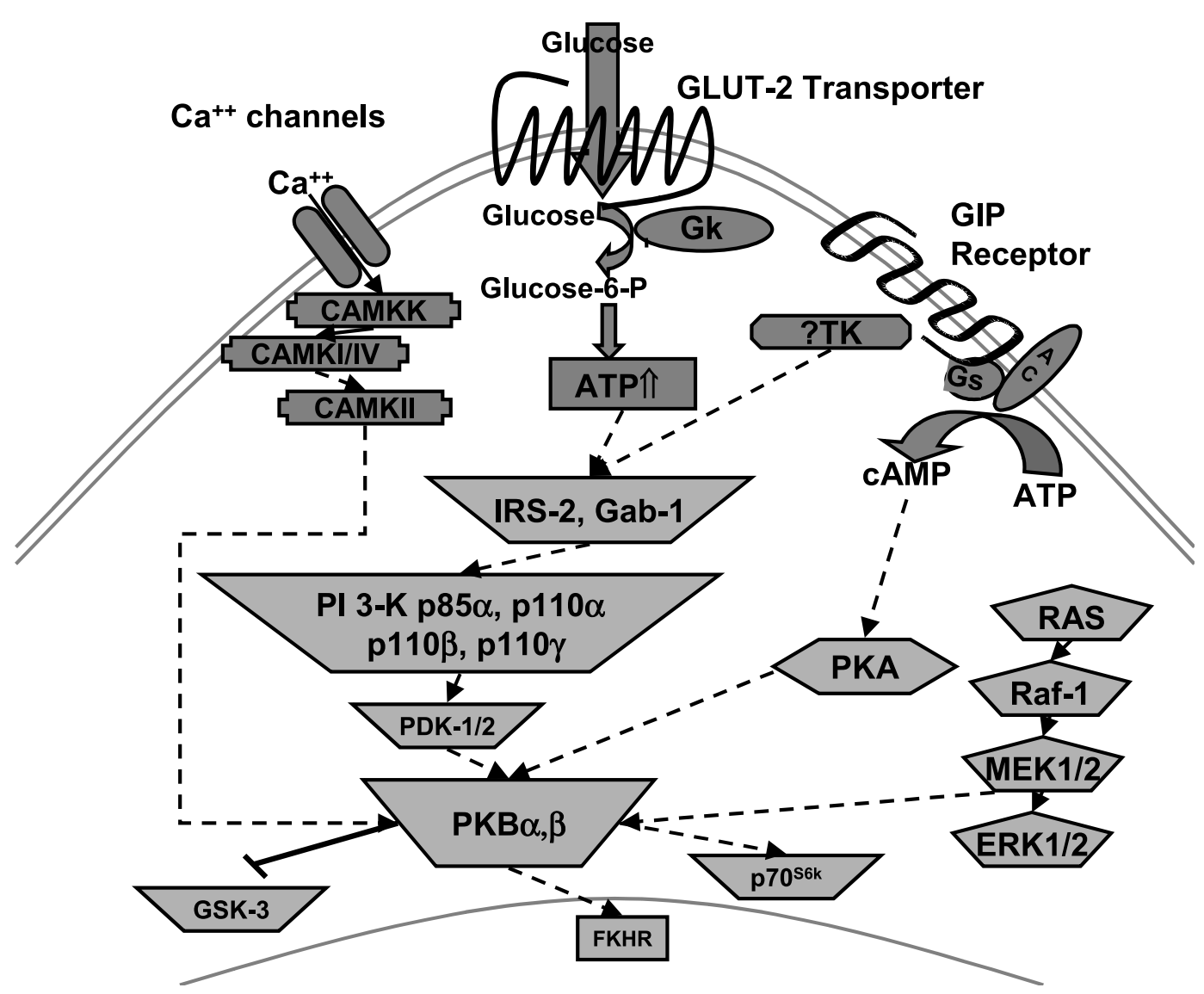

Figure 11 Schematic representation of mechanisms of PKB stimulation by GIP and glucose in pancreatic $\beta$-cells. Gab-1, insulin receptor substrate isoform Gab-1; GSK-3, glycogen synthase kinase-3; p70 ${ }^{\text {S6k }}$, p70 S6 kinase; p85 $\alpha$, $\mathrm{PI} 3$-kinase regulatory isoform $\mathrm{p} 85 \alpha ; \mathrm{p} 110 \alpha, \mathrm{p} 110 \beta, \mathrm{p} 110 \gamma$, catalytic isoforms $\mathrm{p} 110 \alpha, \mathrm{p} 110 \beta$ and $\mathrm{p} 110 \gamma ;$ other abbreviations as in Fig. 1.

less specific than reported in in vitro kinase assays. The inhibitors used in our study may be even less selective in in vivo assays, because of the necessity to use greater concentrations of inhibitors. These fundamental problems may be circumvented by the coexpression of inhibitory kinases or dominant negative constructs such as inhibitory protein kinase (PKI; Olson \& Uhler 1991). Several reports have described activation of PKA/CREB signaling by members of the ras-Raf-MEK-1/2 pathway (Hoffmann et al. 1999, Seternes et al. 1999). It is noteworthy that inhibition of PKA/CREB by MAPK signaling at the level of MEK-1 or downstream has not yet been demonstrated in any cell type, and may thus be specific for mitogenic signaling by $G$ protein-coupled receptors in $\beta$-cells. Recently, we were able to demonstrate a similar pattern of interaction in INS-1 cells stimulated with GLP-1. In these experiments we were able to show that the inhibitory interaction between MAPK and PKA/CREB was dependent upon signaling by PKA (K Trümper \& D Hörsch unpublished data). It should be noted that INS-1 cells are more sensitive to GLP-1 than to GIP as growth and anti-apoptotic factors (Trümper et al. 2001, authors' unpublished observations, this study). These effects may be caused by lower expression of GIP receptors on INS-1 cells compared with GLP-1 receptors. Thus concomitant stimulation of both incretin hormones may be required for the mitogenic and anti-apoptotic homeostasis of $\beta$-cells.

Because tyrosine phosphorylation is a key element in the signal transduction of glucose- and GIP-stimulated signaling modules, we investigated the nature of the tyrosine kinase involved. Here, members of the epidermal growth factor family and the src-family of non-receptor tyrosine kinases are candidate tyrosine kinases (Della Rocca et al. 1999, Hackel et al. 1999, Bisotto \& Fixman 2001, K Trümper \& D Hörsch unpublished data).

In summary, we have shown that GIP is a growth and anti-apoptotic factor for $\beta$-cells by pleiotropic activation of PKA/CREB, MAPK and PI3-kinase/PKB pathways, which are tightly linked to each other by cross-talk, and also to $\mathrm{Ca}^{2+}$ signaling and glucose metabolism. The pleiotropic mechanism of the mitogenic and anti-apoptotic signaling by GIP implies that $\beta$-cell growth factors such as 
insulin-like growth factor-1 (Hügl et al. 1999) or growth hormone (Nielsen et al.2001) may interact not only by the activation of cognate receptors at the cellular surface, but also by the differential pleiotropic coactivation of signaling cascades that may be needed for the regulation of $\beta$-cell mass and function in health and disease.

\section{Acknowledgements}

This research was supported by a grant from the Deutsche Forschungsgemeinschaft to D H (Ho 1762/2-1). Parts of this study are contained in the medical thesis of A Trümper.

\section{References}

Asfari M, Janjic D, Meda P, Li G, Halban PA \& Wollheim CB 1992 Establishment of 2-mercaptoethanol-dependent differentiated insulin-secreting cell lines. Endocrinology 130 167-178.

Bisotto S \& Fixman ED 2001 Src-family tyrosine kinases, phosphoinositide 3-kinase and Gab1 regulate extracellular signal related kinase 1 activation induced by the type A endothelin-1 G-protein-coupled receptor. Biochemical Journal 360 77-85.

Castrillo A, Bodelon OG \& Bosca L 2000 Inhibitory effect of IGF-1 on type 2 nitric oxide synthase expression in Ins- 1 cells and protection against activation dependent apoptosis. Involvement of phosphatidylinositol 3-kinase. Diabetes 49 209-217.

Davies SP, Reddy H, Caivano M \& Cohen P 2000 Specificity and mechanism of action of some commonly used protein kinase inhibitors. Biochemical Journal 351 95-105.

Della Rocca GJ, Maudsley S, Daaka Y, Lefkowitz RJ \& Luttrell LM 1999 Pleiotropic coupling of G protein-coupled receptors to the mitogen-activated protein kinase cascade. Role of focal adhesions and receptor tyrosine kinases. Journal of Biological Chemistry 274 13978-13984.

Fehmann HC, Göke R \& Göke B 1995 Cell and molecular biology of the incretin hormones glucagon-like peptide-1 and glucosedependent insulin releasing polypeptide. Endocrine Reviews 16 390-410.

Frödin M, Sekine N, Roche E, Filloux C, Prentki M, Wollheim CB \& Vanobberghen E 1995 Glucose, other secretagogues, and nerve growth-factor stimulate mitogen- activated protein-kinase in the insulin-secreting $\beta$-cell line, INS-1. Journal of Biological Chemistry $2707882-7889$.

Hackel PO, Zwick E, Prenzel N \& Ullrich A 1999 Epidermal growth factor receptors: critical mediators of multiple receptor pathways. Current Opinion in Cellular Biology 11 184-189.

Hoffmann R, Baillie GS, MacKenzie SJ, Yarwood SJ \& Houslay MD 1999 The MAP kinase ERK2 inhibits the cyclic AMP-specific phosphodiesterase HSPDE4D3 by phosphorylating it at Ser579. EMBO Journal 18 893-903.

Hügl SR, White MF, Rhodes CJ 1998 Insulin-like-growth-factor-1 (IGF-1)-stimulated pancreatic $\beta$-cell growth is glucose-dependent synergistic activation of insulin-receptor substrate-mediated signal-transduction pathways by glucose and IGF-1 in INS-1 cells. Journal of Biological Chemistry 273 17771-17779.

Huong PL, Kolk AH, Eggelte TA, Verstijnen CP, Gilis H \& Hendriks JT 1991 Measurement of antigen specific lymphocyte proliferation using 5-bromo-deoxyuridine incorporation. An easy and low cost alternative to radioactive thymidine incorporation. Journal of Immunological Methods 5 243-245.

Isihara H \& Wollheim CB 2000 What couples glycolysis to mitochondrial signal generation in glucose-stimulated insulin secretion. IUBMB Life 49 391-395.

Kerouz N, Hörsch D, Pons S \& Kahn CR 1997 Differential regulation of insulin receptor substrates- 1 and -2 (IRS-1 and
IRS-2) and phosphatidylinositol-3 kinase isoforms in liver and muscle of the obese diabetic (ob/ob) mouse. Journal of Clinical Investigation 100 3164-3172.

Kubota A, Yamada Y, Yasuda K, Someya Y, Ihara Y, Kagimoto S, Watanabe R, Kuroe A, Ishida H \& Seino Y 1997 Gastric inhibitory polypeptide activates MAP kinase through the Wortmannin-sensitive and -insensitive pathways. Biochemical and Biophysical Research Communications 235 171-175.

Lenzen S, Brand FH \& Panten U 1988 Structural requirements of alloxan and ninhydrin for glucokinase inhibition and of glucose for protection against inhibition. British Journal of Pharmacology 95 851-859.

Li G, Hidaka H \& Wollheim CB 1992 Inhibition of voltage-gated $\mathrm{Ca} 2+$ channels and insulin secretion in HIT cells by the Ca2+/ calmodulin-dependent protein kinase II inhibitor KN62: comparison with antagonists of calmodulin and L-type Ca2+ channels. Molecular Pharmacology 42 489-498.

Marley PD \& Thomson KA 1996 The Ca++/calmodulin-dependent protein kinase II inhibitors KN62 and KN93, and their inactive analogues KN04 and KN92, inhibit nicotinic activation of tyrosine hydroxylase in bovine chromaffin cells. Biochemical and Biophysical Research Communications 221 15-18.

Miyawaki K, Yamada Y, Yano H, Niwa H, Ban N, Ihara Y, Kubota A, Fujimoto S, Kajikawa M, Kuroe A, Tsuda K, Hashimoto H, Yamashita T, Jomori T, Tashiro F, Miyazaki JI \& Seino Y 1999 Glucose intolerance caused by a defect in the entero-insular axis: a study in gastric inhibitory polypeptide receptor knockout mice. PNAS 96 14843-14847.

Moley KH \& Mueckler MM 2000 Glucose transport and apoptosis. Apoptosis $\mathbf{5}$ 99-105.

Nielsen JH, Galsgaard ED, Moldrup A, Friedrichsen BN, Billestrup N, Hansen JA, Lee YC, Carlsson C 2001 Regulation of $\beta$-cell mass by hormones and growth factors. Diabetes 50 (Suppl 1) S25-S29.

Oehm A, Behrmann I, Falk W, Pawlita M, Maier G, Klas C, Li-Weber M, Richards S, Dhein J \& Trauth BC 1992 Purification and molecular cloning of the APO-1 cell surface antigen, a member of the tumor necrosis factor/nerve growth factor receptor superfamily. Sequence identity with the Fas antigen. Journal of Biological Chemistry 267 10709-10715.

Olson SR \& Uhler MD 1991 Inhibition of protein kinase-A by overexpression of the cloned human protein kinase inhibitor. Molecular Endocrinology 5 1246-1256.

Pawson T \& Saxton TM 1999 Signaling networks - do all roads lead to the same genes? Cell 97 675-678.

Porte Jr D \& Kahn SE 2001 Beta-cell dysfunction and failure in type II diabetes: potential mechanisms. Diabetes 50 (Suppl 1) S160S163.

Rane SG \& Reddy EP 2000 Cell cycle control of pancreatic beta cell proliferation. Frontiers in Bioscience $\mathbf{5}$ 1-26.

Ronner P, Naumann CM, Friel E 2001 Effects of glucose and amino acids on free ADP in betaHC9 insulin-secreting cells. Diabetes $\mathbf{5 0}$ 291-300

Seternes OM, Johansen B \& Moens U 1999 A dominant role for the Raf-MEK pathway in forskolin, 12-O-tetradecanoyl-phorbol acetate, and platelet-derived growth factor-induced CREB (cAMP-responsive element). Molecular Endocrinology 13 10711083.

Simon MA 2000 Receptor tyrosine kinase: specific outcomes from general signals. Cell 103 13-15.

Straub S \& Sharp GWG 1996 Glucose-dependent insulinotropic polypeptide stimulates insulin secretion via increased cyclic AMP and $(\mathrm{Ca} 2+)$ and a Wortmannin-sensitive signaling pathway. Biochemical and Biophysical Research Communications 254 369-374.

Sun P, Lou L \& Maurer RA 1996 Regulation of activating transcription factor- 1 and the cAMP response element-binding protein by $\mathrm{Ca} 2+/$ calmodulin-dependent protein kinase I, II and IV. Journal of Biological Chemistry 271 3066-3073. 
Trümper A, Trümper K, Trusheim H, Arnold R, Göke B \& Hörsch D 2001 Glucose-dependent insulinotropic polypeptide is a growth factor for beta (INS-1) cells by pleiotropic signaling. Molecular Endocrinology 15 1559-1570.

Usdin TB, Mezey E, Button DC, Brownstein MJ \& Bonner TI 1993 Gastric inhibitory polypeptide receptor, a member of the secretinvasoactive intestinal peptide receptor family, is widely distributed in peripheral organs and in the brain. Endocrinology 133 2861-2870.

Volz A, Göke R, Lankat-Buttgereit B, Fehmann HC, Bode HP \& Göke B 1996 Molecular cloning, functional expression, and signal transduction of the GIP-receptor cloned from a human insulinoma. FEBS Letters 373 23-29.

Volz-Peters A, Peters H, Berghöfer P, Jiang J, Göke R, Balling R, Wanke R, Wolf E \& Göke B 2000 Expression of a dominantnegative GIP receptor induces diabetes mellitus in transgenic mice.
Experimental and Clinical Endocrinology and Diabetes 108 (Suppl 1) 40 (Abstract).

Weir CG, Laybutt DR, Kaneto H, Bonner-Weir S \& Sharma A 2001 Beta-cell adaptation and decompensation during the progress of diabetes. Diabetes 50 (Suppl 1) S154-S159.

Wheeler MB, Gelling RW, McIntosh CH, Georgiou J \& Pederson RA 1995 Functional expression of the rat islet glucose-dependent insulinotropic polypeptide receptor: ligand binding and intracellular signaling properties. Endocrinology 136 4629-4639.

Yip RGC \& Wolfe MM 2000 GIP biology and fat metabolism. Life Science 66 91-103.

Received 8 April 2002

Accepted 19 April 2002 